\title{
An investigation of reosseointegration according to time course after mechanical loosening of the osseointegrated implant fixtures
}

\author{
Sun-Hae Ye, Jin-Hyun Cho, Cheong-Hee Lee* \\ Department of Prosthodontics, School of Dentistry, Kyungpook National University, Daegu, Republic of Korea
}

\begin{abstract}
Purpose: The purpose of this study was to investigate the reosseointegration periods when the rough surface implants, which had complete bone-implant ankylosis, suddenly losed the osseointegration. Materials and Methods: The implants with RBM surface treatment were inserted into both tibias of 23 rabbits. Two implants were submerged into each side. After six weeks, the primary removal torque was measured by Digital torque gauge, and then the implants were replaced and submerged to estimate the level of reosseointegration. After assigned healing periods for each group, the removal torque was measured again. BIC (Bone-Implant contact, \%) ratio was measured through histomorphometric analysis.Paired t-test was processed by SPSS 14.0. One-way ANOVA and Tukey's post-hoc test was processed to analyze statistically significant differences among the groups. Results: In comparison with the primary removal torque, the secondary removal torque was increased after 11 days and significantly increased from 2 weeks. In fluorochrome labeling, the origin of mineralization was observed after 7 days, which showed as fluorescent bands around the boneimplant interfaces. After 11 days, the bone formation was apparent, and it is increased continuously with the passage of the time. Conclusion: In 11 days after the implant replacement, the secondary removal torque was almost as same as the primary value, and was significantly higher from 2 weeks. The mineralized shapes were observed in 7 days after the implant replacement, and then the bone formation appeared visibly in 11 days. (J Dent Rehabil Appl Sci 2015;31(3):203-11)
\end{abstract}

Key words: mechanical fixture loosening; reosseointegration; removal torque

\section{Introduction}

Since Brånemark et al. ${ }^{1}$ introduced the concept of osseointegration, various restorations with implants have been developed and established. In clinical view, the successful osseointegration is defined as the implants firmly fixed and retained into the alveolar bone under functional load.

Typically, through the secondary surgery and the restoration procedures after osseointegration of the implant has been established, the implant prosthetics aremade. During the secondary surgery and pros-

*Correspondence to: Cheong-Hee Lee

Professor, Department of Prosthodontics, Kyungpook National University Dental Hospital, 2175, Dalgubeoldae-ro, Jung-gu, Daegu, 41904, Republic of Korea

Tel: +82-53-600-7673, Fax: +82-53-427-0778, E-mail: chlee@knu.ac.kr

Received: June 22, 2015/Last Revision: July 29, 2015/Accepted: July 30, 2015 thetic procedures, the screws are used. As a result, the fixtures are under torsion. If the osseointegration is not sufficient or the torsion is excessive, the separation of bone-implant interfaces may occur. In spite of the separation between bone and implant, the reosseointegration clinically appears after sufficient time without having any load.

To evaluate the resettlement periods for clinically applicable osseointegration after the separation of bone-implant interface, Jang et al. ${ }^{2}$ reported in the rabbit experiment with 4 weeks of resettlement that reosseointegration occurs and the removal torque was 
significantly increased in 4 weeks after the osseointegration had been splitted. In addition, Hwang et al. ${ }^{3}$ reported in the rabbit experiment with various resettlement periods for smooth surface implants that the higher osseointegration could be acquired in 2 weeks after primary osseointegration had been broken.

In this study, the experiment twas designed to evaluate reosseointegration periods for the rough surface implants after mechanical loosening of the osseointergrated implants. First, the implants with RBM (Resorbable Blast Media) surface treatments were inserted into rabbits' tibias. Second, the intentional mechanical loosening was applied on the implants, so that the separation of bone-implant interface occurred. Then, the level of osseointegration as time elapsed and the bone reaction around bone-implant interfaces were observed by means of torque gauge and histomorphometric analysis.

\section{Materials and Methods}

After the fabrication of the implants made of pure titanium, which have $3.75 \mathrm{~mm}$ diameter and 4 $\mathrm{mm}$ length, the RBM surface treatment (Megazen, Kyungsan, Korea) were processed (Fig. 1). The 23 rabbits for the experiment (Female, New Zealand white), which weigh more than $3.5 \mathrm{~kg}$, were under general anesthesia by intramuscular injection of $2 \%$ Xylazine (Rompun, Bayer Korea, Seoul, Korea), sul-

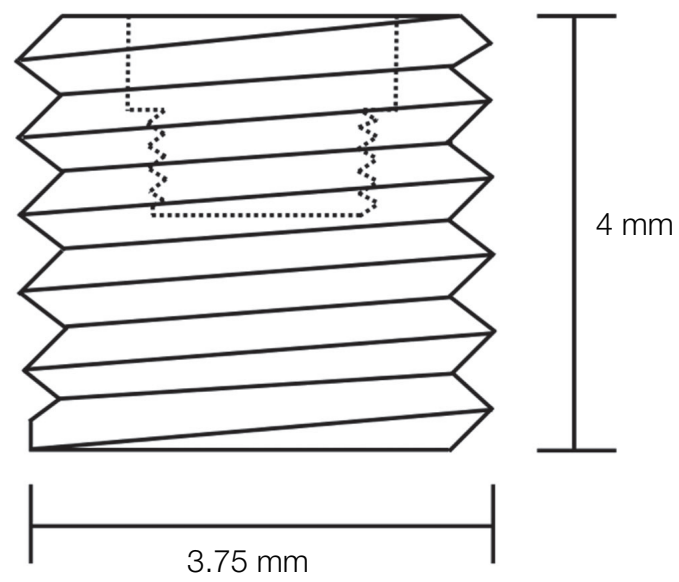

Fig. 1. Schematic diagram of experimental implant. furic acid atrophine (DAIHAN pharm, Co., LTD, Seoul, Korea), and Zoletil 50 (Virbac Lab., Carros, France) $0.15 \mathrm{~mL} / \mathrm{Kg}$ at 5 -minute intervals. Then, two implants were placed on each tibia (Fig. 2). Total 92 implants were inserted and submerged in typical manner. Novin-50 (Bayer Korea, Seoul, Korea) 0.44 $\mathrm{ml} / \mathrm{Kg}$ for antibiotics was injected into the muscle after suture. Negasunt (Bayer Korea) for the healing agent was applied on the surgical site and let it be to form osseointegration for 6 weeks.

\section{Primary removal torque measurement}

Except 2 rabbits for histomorphometric anaylsis, after 6 weeks of the implant surgery, the counterclockwise forces were exerted to measure the removal torques of all implants, and the primary measurements were recorded by Digital torque gauge (MGT12, Mark-10 Co., Copiague, NY, USA)(Fig. 3).Then, the implants were replaced around their

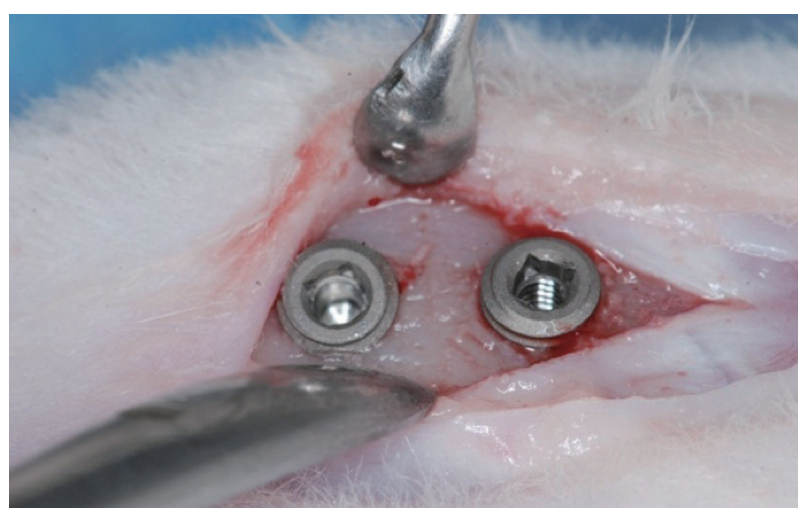

Fig. 2. Two implants were placed on each tibia.

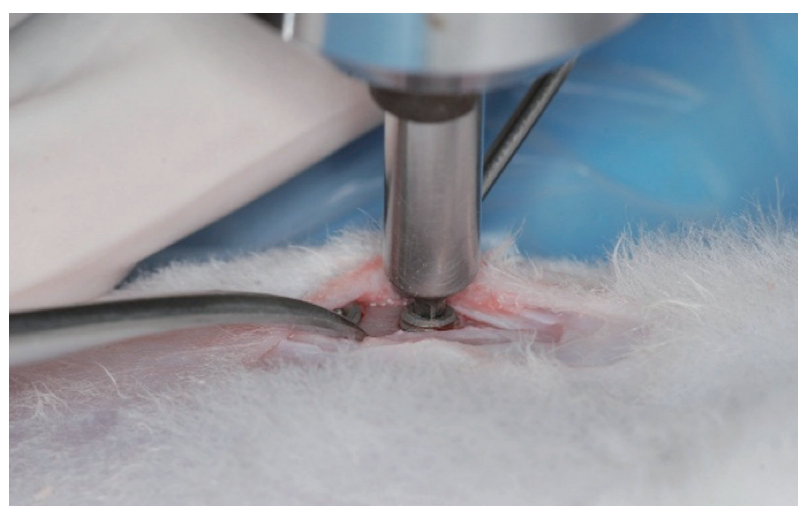

Fig. 3. Removal torque were measured by digital torque gauge. 
Table 1. Experimental groups

\begin{tabular}{cccc}
\hline Group & $\begin{array}{c}\text { 1st healing } \\
\text { time (weeks) }\end{array}$ & N & $\begin{array}{c}\text { Interval between 1st } \\
\text { and 2nd removal } \\
\text { torque test }\end{array}$ \\
\hline I & 6 & 12 & 4 days \\
II & 6 & 12 & 7 days \\
III & 6 & 12 & 11 days \\
IV & 6 & 12 & 2 weeks \\
V & 6 & 12 & 4 weeks \\
VI & 6 & 12 & 6 weeks \\
VII & 6 & 12 & 8 weeks \\
\hline
\end{tabular}

original position, and submerged again to obtain osseointegration around bone-implant interfaces. The groups were divided into 7 groups, 3 rabbits per each group (Table 1).

\section{Histomorphometric analysis}

To compare the tissue morphology with the experimental group, 2 rabbits were excluded from the primary removal torque measurement. Instead, 4 tissue specimens were fabricated from inferior implants submerged into both sides of tibias. To evaluate bone formation through histomorphometric analysis under fluorochrome labeling, tetracycline (Tetracycline hydrochloride, Sigma-Aldrich, St. Louis, MO, USA) 15 $\mathrm{mg} / \mathrm{kg}$ was injected intramuscularly to all groups in 1 day, 3 days, 10 days, and 13 days after the surgery, and 3 days before measuring the secondary removal torque for Group V. Demeclocycline (Demeclocyline hydrochloride, Sigma-Aldrich, St. Louis, MO, USA) 15 $\mathrm{mg} / \mathrm{kg}$ was also injected intramuscularly to Group VI and VII in 3 days before measuring the secondary removal torque to observe the bone formation after the osseointegration was established. While measuring the secondary removal torque, the specimens were made of the implants from the inferior part of rabbits' left tibia except for exerting removal forces (Table 2).
Table 2. Experimental groups for histomorphometric analysis

\begin{tabular}{cccc}
\hline Group & $\begin{array}{c}\text { 1st healing } \\
\text { time (weeks) }\end{array}$ & N & $\begin{array}{c}\text { Interval after 1st } \\
\text { removal torque test }\end{array}$ \\
\hline C & 6 & 4 & 0 day \\
I & 6 & 3 & 4 days \\
II & 6 & 3 & 7 days \\
III & 6 & 3 & 11 days \\
IV & 6 & 3 & 2 weeks \\
V & 6 & 3 & 4 weeks \\
VI & 6 & 3 & 6 weeks \\
VII & 6 & 3 & 8 weeks \\
\hline
\end{tabular}

In optical microscope $(\times 20)$ and fluorescence microscope analysis, BIC (Bone-Implant contact, \%) ratio was obtained around the cortical bone area, and the new bone formation was compared and analyzed.

\section{Secondary removal torque measurement}

To evaluate the level of the osseointegration for the replaced implants according to time passed, each group was given different healing periods - 4 days, 7 days, 11 days, 2 weeks, 4 weeks, 6 weeks and 8 weeks. After healing periods, the secondary removal torque was measured.

\section{Statistical analysis}

The average rate of variation for the secondary removal torque regarding the primary removal torque was obtained to observe the change of the removal torque in each group.

To verify the differences between primary and secondary removal torque were significant, paired ttest was applied in all groups. In Group I, Wilcoxon signed rank test (Shapiro-Wilk test, $P=0.043$ ), one of nonparametric tests was used.

All statistical analysis were responsible for PASW 18.0, the significance level was 0.05 . 


\section{Results}

\section{Removal torque}

After 6 weeks of the implant placement, the primary removal torque was obtained. Then, the secondary removal torque was measured in each group with the passage of time. The mean value of primary and secondary removal torque was acquired in each group and the rate of increase was calculated (Fig. 4, Table 3).

The secondary removal torque was significantly decreased in Group I, II. However, it was increased in Group III and significantly increased in Group IV, V, VI and VII.
To compare among the groups, the significant differences were found between Group I, II and the others, and between Group III and Group VI, VII. Also, between Group IV, V and Group VII showed significant differences.

\section{Histomorphometric analysis}

In optical microscope $(\times 20)$ and fluorescence microscope, the BIC ratios of 7 groups were compared. There were statistically significant differences between the control group and Group VII, and between Group I, II and Group V, VI, and VII, and between Group III, IV and Group VII (Fig. 5, Table 4).

Table 3. The primary, secondary removal torque and rate of increase

\begin{tabular}{cccccc}
\hline Group & $\mathrm{N}$ & Primary removal torque & Secondary removal torque & Rate of increase $(\%)$ & $P$ value* \\
\hline I & 9 & $19.79 \pm 6.10$ & $8.32 \pm 4.15^{\mathrm{A}}$ & -59.87 & $<0.008$ \\
II & 9 & $19.10 \pm 6.23$ & $11.92 \pm 4.78^{\mathrm{A}}$ & -39.03 & $<.23$ \\
III & 9 & $24.40 \pm 7.97$ & $25.78 \pm 8.35^{\mathrm{B}}$ & 25.33 & 0.001 \\
IV & 9 & $18.06 \pm 5.35$ & $22.24 \pm 5.93^{\mathrm{BC}}$ & 51.23 & $<0.001$ \\
V & 9 & $22.09 \pm 6.92$ & $32.17 \pm 6.69^{\mathrm{BC}}$ & 42.66 & $<0.001$ \\
VI & 9 & $17.32 \pm 3.76$ & $24.48 \pm 6.82^{\mathrm{CD}}$ & 63.33 & $<0.004$ \\
VII & 9 & $23.43 \pm 3.73$ & $38.10 \pm 7.07^{\mathrm{D}}$ & & $<0.001$ \\
$P$ value** & 0.092 & $<0.001$ & & & \\
\hline
\end{tabular}

* $P$ value determined by paired-t test except for Group I (Wilcoxon signed rank test).

** $P$ value determined by one-way ANOVA.

$\mathrm{A}, \mathrm{B}, \mathrm{C}, \mathrm{D}$ The same character denoted no significant differences by Tukey's multiple comparison at $\alpha=0.05$.

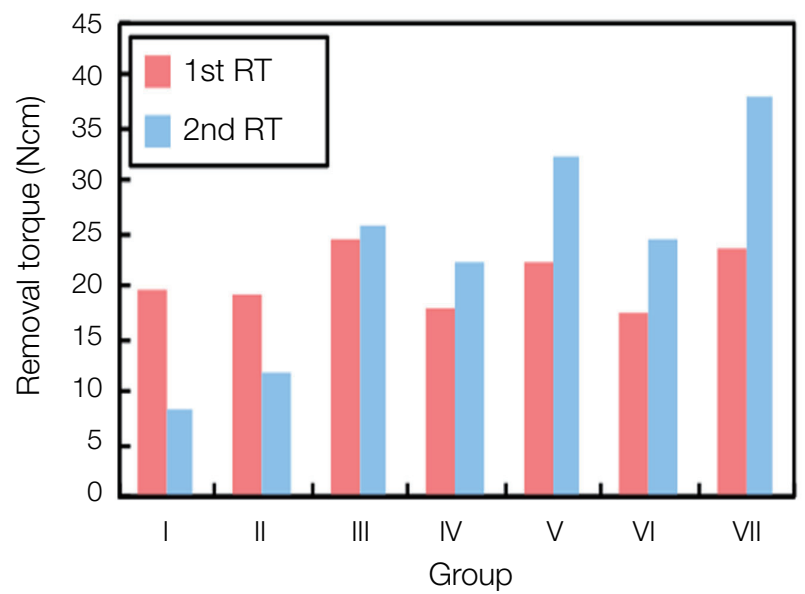

Fig. 4. Comparison of 1 st and 2 nd removal torques in each group. 
Table 4. BIC result from histomorphometric analysis (\%)

\begin{tabular}{clll}
\hline Group & $\mathrm{N}$ & Mean $\pm \mathrm{SD}$ & $P$ value* \\
\hline Control & 8 & $27.45 \pm 9.88^{\mathrm{AB}}$ & $<0.001$ \\
I & 6 & $11.84 \pm 6.45^{\mathrm{A}}$ & \\
II & 6 & $10.38 \pm 7.12^{\mathrm{A}}$ & \\
III & 6 & $25.56 \pm 10.94^{\mathrm{AB}}$ & \\
IV & 6 & $37.54 \pm 11.20^{\mathrm{BC}}$ & \\
V & 6 & $34.08 \pm 11.59^{\mathrm{BC}}$ & \\
VI & 6 & $48.86 \pm 10.66^{\mathrm{C}}$ & \\
VII & 6 &
\end{tabular}

$* P$ value determined by one-way ANOVA.

$\mathrm{A}, \mathrm{BC}, \mathrm{D}$ The same character denoted no significant differences by Tukey's multiple comparison at $\alpha=0.05$.

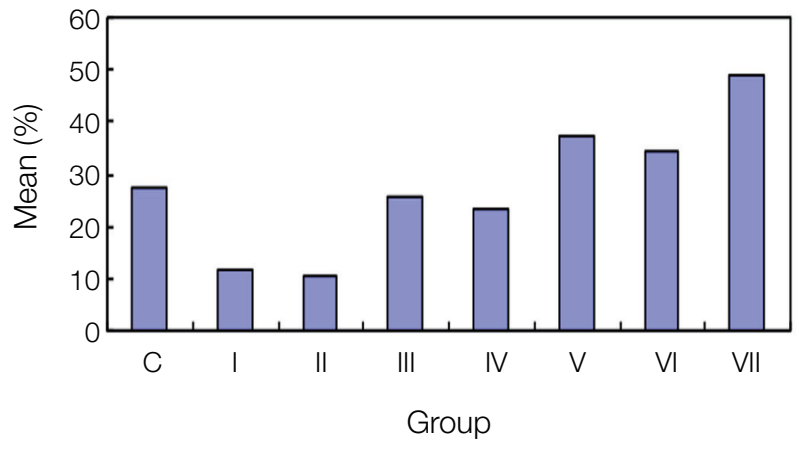

Fig. 5. Mean BIC in each group.

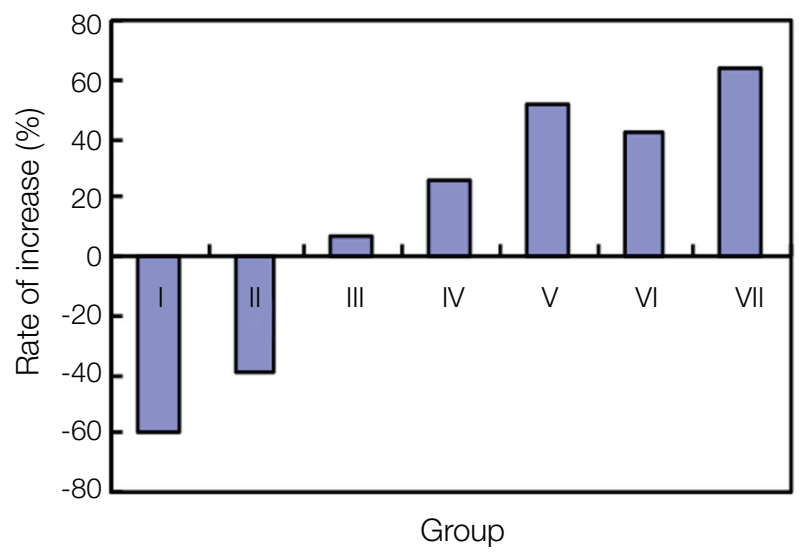

Fig. 6. Rate of increase between 1st and 2nd removal torques in each group.

that reosseointegration occurs without any significant difference with the control group, but the degree of osseointegration and BIC hardly changed. In the rabbit experiment of bone-implant reosseointegration, which had 6 week periods for initial osseointegration and 4 weeks of resettlement periods after forcing intentional mobility, Jang et al. ${ }^{2}$ observed that the removal torques were sharply increased than the initial condition. In the study of the removal torque for the smooth surface implants according to resettlement periods after iatrogenic mobilization, Hwang et al. ${ }^{3}$ reported that the removal torque were increased in all cases if the induction of reosseointegration were longer than 2 weeks. 

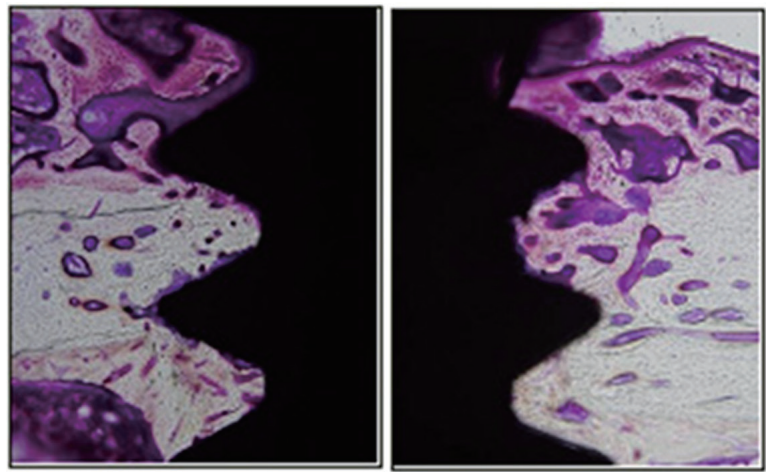

Control group
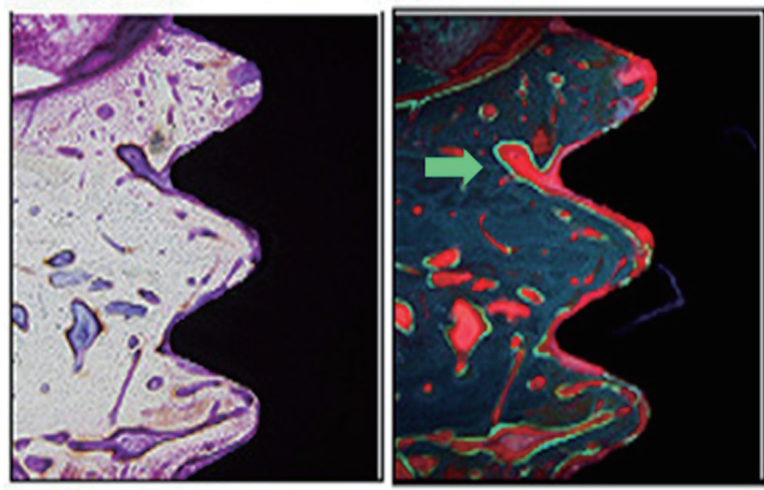

Control II
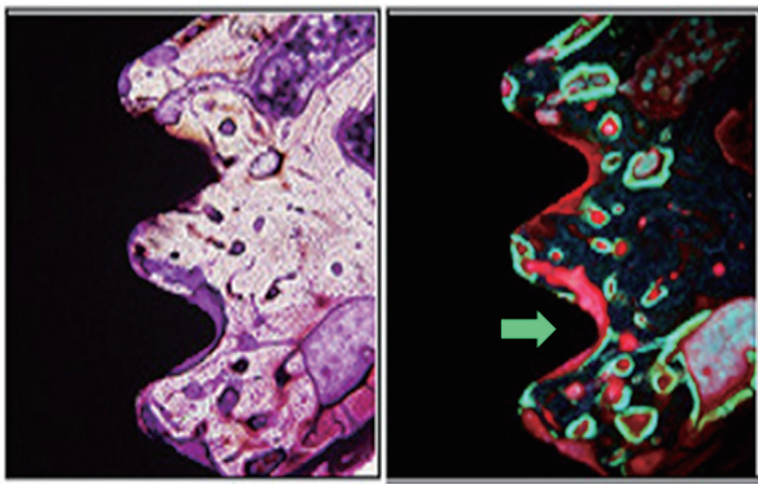

Control IV
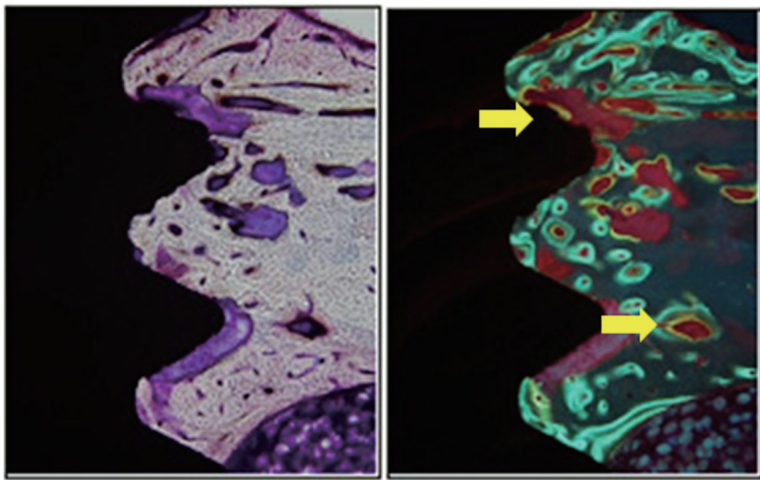

Control VI
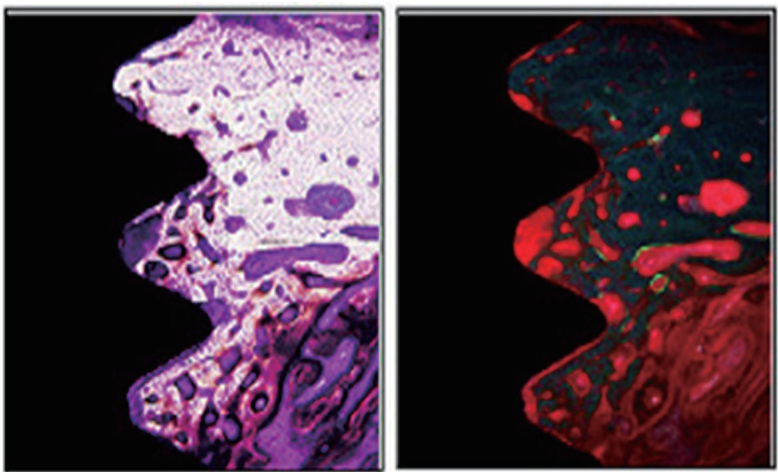

Group I
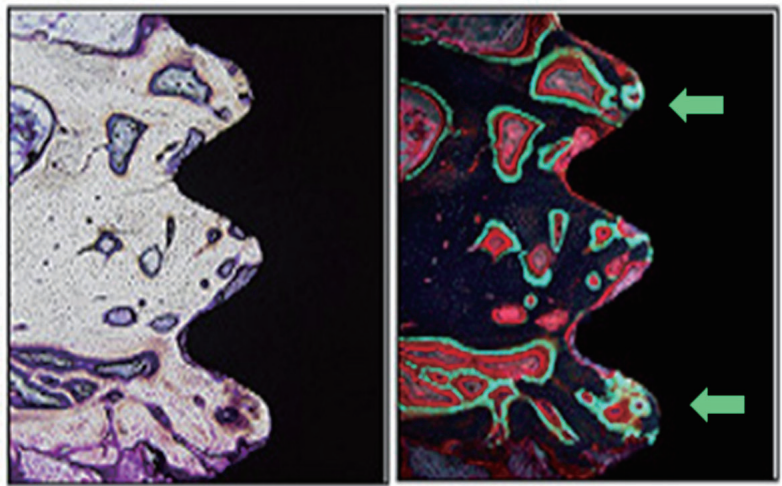

Group III
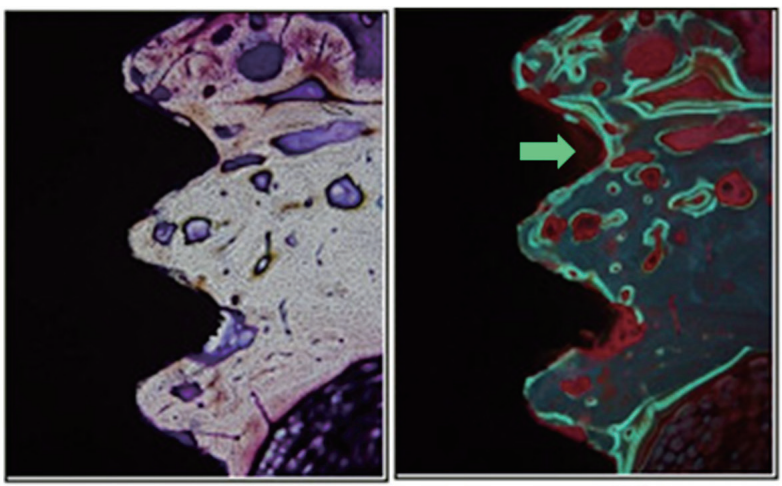

Group V
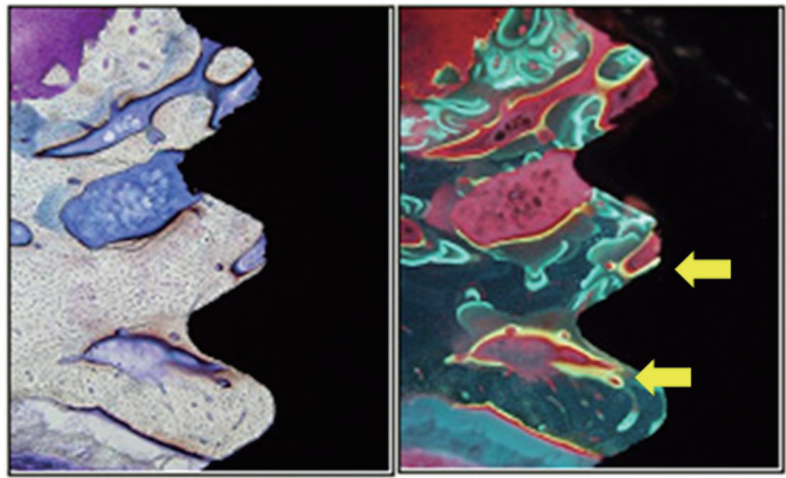

Group VII

Fig. 7. Histomorphometric analysis of control group and experimental groups. Tetracycline initially appeared on the bone surrounding the implant in Group II, and it became apparent in Group IIland more as time passed (Green band; Green arrow). Demeclocycline continued to appear in Groups VI and VII (Yellow band; Yellow arrow). 
From the previous results, we anticipate that the bone-implant reosseointegration after mechanical loosening is obtained if the sufficient healing periods are given. However, the most implants in the clinics have surface treatments. Cochran ${ }^{5}$ have indicated that the rough surface implants made in various methods had higher BIC and removal torque than smooth surface implants. To evaluate the periods to acquire the sufficient level of osseointegration for implants with surface treatment, the implants were placed into rabbits' tibias, and complete osseointegration was induced by assigning 6 week healing periods. Then, the primary removal torque was measured, and the implants were submerged again. After 4 days, 7 days, 11 days, 15 days, 4 weeks, 6 weeks, and 8 weeks of implant replacements, the secondary removal torque was measured and compared with the primary removal torque.

Sennerby et al. ${ }^{6}$ reported in the study of comparison of submerged implants into cancellous bone and cortical bone of rabbits after 6 weeks, 3 months, and 6 months that the removal torque remained constant after 6 weeks for the cortical bone. Therefore, in this study the periods for initial osseointegration were determined to 6 weeks for tibias, which correspond to the cortical bone.

Hwang et al. ${ }^{3}$ observed that the removal torque was decreased in 4 days and 1 week after resettlement, but increased significantly in 2 weeks. In 6 weeks, it was increased, but not significantly. Therefore, he doubted the possibility of continuous bone formation, and suggested the further research. However, in this study, the result showed that the secondary removal torque was lower than the primary removal torque in 4 day and 7 day group as Hwang's result, and became higher in 11 days group, but the difference was insignificant. In 2 week, 4 week, 6 week, and 8 week groups, the secondary removal torques showed significantly higher than their primary values. Therefore, the result indicates that RBM surface provides rapid and constant bone-implant osseointegration compared to smooth surface. It is considered that the higher osseointegration is achievable, which disagrees the study of Sennerby et al., ${ }^{6}$ who reported that the removal torque remains constant after 6 weeks.
According to the study of Roberts et al., ${ }^{7-9}$ the formation of immature bone begins in 3 days, and the bone surrounding the implants matures in 6 weeks in rabbits' tibias. Sennerby et al..$^{10}$ observed the immature bone in first 7 days, and the matured bone around implants in 6 weeks. In this study, under fluorochrome labeling, the fluorescent substances were observed in 7 days, and broadly distributed in 11 days, and then became widespread afterwards. Moreover, the bone formation had constantly occurred for 8 weeks. From the result, it is assumed that the removal torque was barely influenced because mineralization around the implant fixtures did not begin, even though the osteoid tissue formed and started its mineralization in 4 days and 7 days. In 11 days, the sufficient mineralization affected the removal torque, and it became higher afterwards. In contrast to Hwang et al., ${ }^{3}$ the removal torque and BIC were significantly increased in 8 weeks of resettlement. It is considered that the implants with surface treatment support the continuous bone formation as the study of Schwartz et al., ${ }^{11}$ which suggested that the rough surfaces of the implants with surface treatment stimulate proliferation and differentiation of osteoblasts to contribute preferable bone formation.

In conclusion, mineralization of the immature bone begun in 7 days became sufficient reosseointegration in 11 days. In other words, it reached boneimplant interfaces in 11 days, and if we consider that the metabolic rates of human are 3 times higher than those of rabbits, the periods are about 33 days in human. Therefore, when the implant fixtures in human are under mobility from temporarily damaged osseointegration because of the excessive torsion, it is anticipatable that postponing the occlusal load and assigning about 33 days of the healing periods for resettlement allow reosseointegration in shorter time with higher stability compared with the initial implant placement.

\section{Conclusion}

1. After 4 days and 7 days of replacement, the removal torques were significantly decreased $(P<$ 0.01). 
2. After 11 days of replacement, all experimental groups had higher removal torque, and the increase became statistically significant after 2 weeks $(P<0.05)$.

3. In comparison among the experimental groups, the groups of 4 days and 7 days after replacement showed significantly lower removal torque. The removal torque of 4 weeks, 6 weeks, and 8 weeks after replacement was significantly higher than that of 11 days. The result of 8 weeks after replacement was significantly higher than that of 2 weeks $(P<0.05)$.

4. Fluorochrome labeling revealed that mineralization began in 7 days after replacement. Apparent bone formation occurred from 11th day onwards, widely observed as time elapsed.

If the results apply to human, bone-implant integration become similar to the initial condition in 1 month after osseointegration was damaged. After the 1 month and half passes, it is considered that the bone-implant integration is securely restored.

\section{Acknowledgements}

This research was supported by Kyungpook National University Research Fund, 2012.

\section{Orcid}

Jin-Hyun Cho http://orcid.org/0000-0002-2453-9372

Cheong-Hee Lee http://orcid.org/0000-0002-2005-0801

\section{References}

1. Brånemark PI, Hansson BO, Adell R, Breine U, Lindström J, Hallén O, Ohman A. Osseointegrated implants in the treatment of edentulous jaw. Expe- rience from a 10-years period. Scan J Plast Reconstr Surg Suppl 1977;16:1-132.

2. Jang JH, Cho JH, Lee CH. Study of the re-osseointegration of implant fixture after mechanical unscrewing. J Korean Acad Prosthodont 2010;48:20914.

3. Hwang YJ, Cho JH, Lee CH. Investigation of osseointegration according to the healing time after having iatrogenic mobility of implant fixtures. J Korean Acad Prosthodont 2010;48:308-14.

4. Ivanoff CJ, Sennerby L, Lekholm U. Reintegration of mobilized titanium implants. An experimental study in rabbit tibia. Int J Oral Maxillofac Surg 1997;26:310-5.

5. Cochran DL. A comparison of endosseous dental implant surfaces. J Periodontol 1999;70:1523-39.

6. Sennerby L, Thomsen P, Ericson LE. A morphometric and biomechanic comparison of titanium implants inserted in rabbit cortical and cancellous bone. Int J Oral Maxillofac Implants 1992;7:62-71.

7. Roberts EW, Turley PK, Brezniak N, Fielder PJ. Implants: Bone physiology and metabolism. CDA J 1987;15:54-61.

8. Roberts EW. Bone tissue interface. Int J Oral Implantol 1988;5:71-4.

9. Roberts EW, Smith RK, Zilberman Y, Mozsary PG, Smith RS. Osseous adaptation to continuous loading of rigid endosseous implants. Am J Orthod 1984;86:95-111.

10. Sennerby L, Thomsen P, Ericson LE. Early tissue response to titanium implants inserted in rabbit cortical bone. Part I Light microscopic observations. J Mater Sci Mater Med 1993;4:240-50.

11. Schwartz Z, Kieswetter K, Dean DD, Boyan BD. Underlying mechanisms at the bone-surface interface during regeneration. J Periodontal Res 1997;32: 166-71. 


\section{표면처리 임플란트 고정체의 의원성 동요 후 시간 경과에 따른 재골유착에 관한 연구}

예선혜, 조진현, 이청희*

경북대학교 치의학전문대학원 치과보철학교실

목적: 완전한 골-임플란트 결합을 가졌던 임플란트가 갑자기 골유착을 잃은 경우의 시간에따른 재골유착을 연구하기 위함이다.

연구 재료 및 방법: 23마리 토끼의 좌우 경골에 각각 2개씩 실험목적으로 제작한 RBM임플란트를 식립 후, 6 주 후에 1 차로 비틀림 제거력을 측정한 다음, 임플란트를 다시 재위치 침하시키고, 4일, 7일, 11일, 2주, 4주, 6주, 그리고 8주의 재침하시간 경과 후 2 차로 비틀림 제거력을 측정하고 시편을 제작하여 조직 형태학적 검사를 하였다. 통계학적 검사를 위해 paired t-test를 시행했고, One-way ANOVA와 Tukey's post-hoc test 통해 그룹간 차이를 비교하여 다음과 같은 결 과를 얻었다.

결과: 1차 비틀림 제거력과 비교해봤을 때 2차에서 11일 후에는 증가했으며, 2주 후부터 유의성 있게 증가하였다. 형광 조사검사에서, 7 일 후부터 골-임플란트 계면 사이에 형광밴드가 나타나는 광물화 현상이 관찰되고, 11 일 후부터는 분 명한 골 형성이 나타났다.

결론: 토끼에서는 11 일 이후가 되면 충분한 재골유착을 얻을 수 있었다.

(구강회복응용과학지 2015;31 (3): 203-11)

주요어: 고정체 의원성 동요; 재골유착; 비틀림제거

*교신저자: 이청희

(41940) 대구광역시 중구 달구벌대로 2175 경북대학교 치과병원 치과보철과

Tel: 053-600-7673 | Fax: 053-427-0778 | E-mail: chlee@knu.ac. kr

|접수일: 2015년 6월 22일 | 수정일: 2015년 7월 29일 | 채택일: 2015년 7월 30일 